Article

\title{
Water, Food Availability, and Anthropogenic Influence Determine the Nesting-Site Selection of a Desert-Dwelling Bird, Xinjiang Ground-Jay (Podoces biddulphi)
}

\author{
Yuping Tong ${ }^{1,2,3,4}$, Feng Xu ${ }^{1,2,3,4, * \mathbb{D}}$, David Blank ${ }^{5}$ and Weikang Yang ${ }^{1,2,3, *}$ \\ 1 State Key Laboratory of Desert and Oasis Ecology, Xinjiang Institute of Ecology and Geography, \\ Chinese Academy of Sciences, Urumqi 830011, China; tongyuping123@163.com \\ 2 The Specimen Museum of Xinjiang Institute of Ecology and Geography, Chinese Academy of Sciences, \\ Urumqi 830011, China \\ 3 Mori Wildlife Monitoring and Experimentation Station, Xinjiang Institute of Ecology and Geography, \\ Chinese Academy of Sciences, Mori 831900, China \\ 4 University of Chinese Academy of Sciences, Beijing 100049, China \\ 5 CAS Research Center for Ecology and Environment of Central Asia, Bishkek 720001, Kyrgyzstan; \\ blankdavid958@yahoo.com \\ * Correspondence: xufeng@ms.xjb.ac.cn (F.X.); yangwk@ms.xjb.ac.cn (W.Y.)
}

Citation: Tong, Y.; Xu, F.; Blank, D.; Yang, W. Water, Food Availability, and Anthropogenic Influence Determine the Nesting-Site Selection of a Desert-Dwelling Bird, Xinjiang Ground-Jay (Podoces biddulphi). Sustainability 2021, 13, 5838. https:// doi.org/10.3390/su13115838

Academic Editor: Reuven Yosef

Received: 24 March 2021

Accepted: 20 May 2021

Published: 22 May 2021

Publisher's Note: MDPI stays neutral with regard to jurisdictional claims in published maps and institutional affiliations.

Copyright: (c) 2021 by the authors. Licensee MDPI, Basel, Switzerland. This article is an open access article distributed under the terms and conditions of the Creative Commons Attribution (CC BY) license (https:/ / creativecommons.org/licenses/by/ $4.0 /)$.

\begin{abstract}
Nesting-site selection is an important aspect of the breeding process in birds, as it usually determines nesting and breeding successes. Many factors can affect bird nest-site selection, including anthropogenic disturbance. In an extreme desert environment, such as the Taklamakan Desert in China, birds' survival pressure is high, especially for rare species such as the Xinjiang Ground-jay (Podoces biddulphi). We studied nest-site selection in this species from March 2017 to May 2019. A Chi-square test, independent sample $t$-test, Mann-Whitney $U$-test, and generalized linear models were applied to possible nest-site selection factors for Xinjiang Ground-jays. The main determining factors were the distances to human settlements, water, and the edge of the oasis. Xinjiang Groundjays nested near available water resources for easier access, which is important in arid environments. Individuals chose to nest far from the oasis edges and settlements to increase food availability and reduce interference from human activities, respectively. Overall, water, food availability, and anthropogenic influence were the main factors affecting the nest-site selection of Xinjiang Groundjays in this study. Therefore, these results suggest that there is a trade-off between survival and reproduction. Further studies are required to verify whether similar site preferences may also apply to other desert-dwelling species.
\end{abstract}

Keywords: Taklamakan Desert; generalized linear models; disturbance; food abundance; Podoces biddulphi; nesting site; oasis habitat; edge effect; human influence; breeding success

\section{Introduction}

Nest-site selection is a significant component of habitat selection and is one of the most important factors determining the survival and reproductive success of birds [1,2]. Nest-site selection refers to the choice of a specific location for nesting from all possible sites [3]; such specific sites tend to increase reproductive success. Recent research has focused on factors that may influence this process, including anthropogenic influence, predator pressure, distance to habitat edges, and vegetation characteristics such as vegetation type, plant composition, and spatial structure [4-8]. Moreover, access to water is also an important influencing factor for species inhabiting arid environments.

Deserts are extremely dry environments characterized by high ambient temperatures and low rainfall, species diversity, and population density, resulting in limited food and water supplies for the local species [8,9]. The Taklamakan Desert, located in the Tarim Basin in southern Xinjiang of China, has an extremely dry climate $[10,11]$, an underlying 
surface of quicksand, and sparse vegetation, which together produce a unique and fragile ecosystem [6,12-14]. As such, access to water and food are important limiting factors for the survival and reproduction of animals, especially birds, in this challenging environment.

For oasis-dependent species, the oasis edge is the boundary between the oasis and desert [15]. Vegetation coverage and species diversity are typically lower near the oasis edges than in the central area [16]; the former directly influences insect density and, thus, the resources available to insect-eating birds [17]. In addition, tall vegetation can provide good shelters for parents and nests $[17,18]$. Therefore, birds that reproduce in the desert may prefer to nest near the oasis center; however, this remains to be verified [19].

Anthropogenic influence is an important factor affecting the nest-site selection of birds $[5,20,21]$. Some studies indicate that an increase in human activities can negatively affect breeding bird communities, population dynamics [22], and the nest-site selection of Eurasian magpies (Pica pica) and Northern goshawk (Accipiter gentilis) [23,24]. As the Xinjiang Ground-jay's nesting area is located far from the nearest human settlement, it is unlikely that human activities directly affect the nest-site selection of this species. However, they can indirectly influence this process by changing the natural habitat [25], since farmers have turned the oasis into arable land, reducing the potential areas for this species to nest. Additionally, livestock has been reported to destroy the nests of the Xinjiang Groundjay [25-28]. Therefore, such anthropogenic influence may have a negative influence on its nest-site selection.

The Xinjiang Ground-jay is an endemic bird species mainly distributed in the desert and semi-desert areas of the Taklamakan Desert. These birds build open bowl nests in Tamarisk shrubs between February and June, laying 1-3 eggs per clutch [29]. Limited research has focused on the breeding of Xinjiang Ground-jays and even less on their nestsite selection. This study aimed to reveal the key factors influencing the nest-site selection of Xinjiang Ground-jays and verify if the nest-site selection of desert-dwelling birds is unique compared to birds living in other environments.

\section{Materials and Methods}

\subsection{Study Area}

This study was conducted in Minfeng County, located on the southern edge of the Taklamakan Desert, Xinjiang, China $\left(82^{\circ} 22^{\prime}-85^{\circ} 55^{\prime} \mathrm{E}\right.$ and $\left.35^{\circ} 20^{\prime}-39^{\circ} 29^{\prime} \mathrm{N}\right)$, ranging approximately $55.5 \mathrm{~km}^{2}$. The Taklamakan Desert is the second-largest drift-sand desert in the world and the largest desert in China. It is composed of $85 \%$ active dunes and $15 \%$ fixed or semi-fixed shrub sand piles, which are the main habitats of animals [26,27]. It has a typical continental warm-temperate arid climate with hot, dry summers and cold winters. The frost-free period is approximately 194 days, annual sunshine is $2842.2 \mathrm{~h}$, annual precipitation is $30.5 \mathrm{~mm}$, annual potential evaporation is $2756 \mathrm{~mm}$, and maximum and minimum temperatures are $41.9^{\circ} \mathrm{C}$ and $-23.9^{\circ} \mathrm{C}$, respectively. There are Gobi, oasis, and desert in this area [27]. The vegetation is mainly composed of Tamarisk (Tamarix spp.), Euphrates poplar (Populus euphratica), Alhagi (Alhagi sparsifolia), common reed (Phragmites australis), and Russian boxthorn (Lycium ruthenicum) [28]. Birds of prey, such as the Long-legged buzzard (Buteo rufinus), are the main predators of Xinjiang Ground-jays in the study area, followed by reptiles, such as the Forsyth's toadhead agama (Phrynocephalus forsythii), and insects $[29,30]$.

\subsection{Field Survey}

Nests were identified by searching for and tracking adult birds. For this, we established a transect, which was covered on foot, across the area of suitable nesting shrubs. Once a bird was observed, we marked its location and searched the entire area within a $5 \mathrm{~km}$ buffer for shrubs to find a nest. The nests were numbered and named according to the order in which they were found, and their GPS coordinates were recorded and marked on a map, producing a polygon for the distribution area of Xinjiang Ground-jay nest sites. The study area was then divided into $500 \times 500 \mathrm{~m}^{2}$ plots, among which those including nests 
(Figure 1) (24) were considered nest plots, and those without nests (198) were designated as non-nest plots. For each plot, we assessed two vegetation characteristics (vegetation type and cover), and five distance factors measured in kilometers (distance to water, path, settlement, grazing land, and oasis edge). Vegetation types were determined as trees, shrubs, or herbs according to which had the highest proportion in each plot. Vegetation cover was measured as the proportion of land where vegetation was present in each plot. Distance factors were measured from the center of the plot to the nearest water, path, settlement, grazing land, and oasis edge.

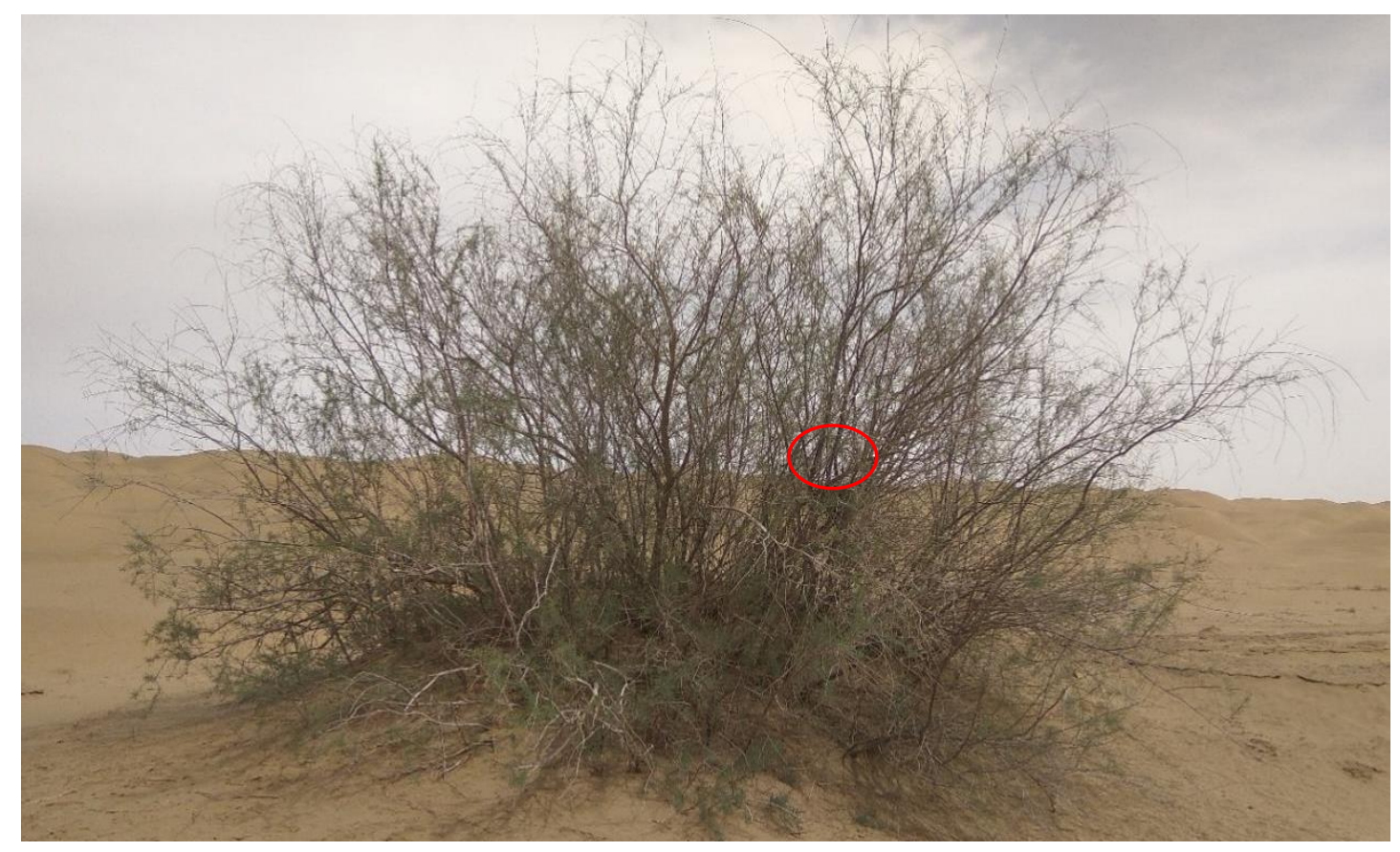

Figure 1. A nest of Xinjiang Ground-jay.

\subsection{Data Analyses}

We used the Chi-square test to compare the difference of vegetation type between the nest and non-nest plots, and the Kolmogorov-Smirnov test to examine the normality of the variables. As the distance to the nearest settlement variable was normally distributed, we used the independent sample $t$-test to assess the significant differences between nest and non-nest plots. Further, because the other six variables were not normally distributed, we used the Mann-Whitney $U$-test to evaluate the significant differences between the two types of plots. The value of statistical significance was set as 0.05 .

Generalized linear models were used to determine the nest-site selection of the Xinjiang Ground-jay. The minimum adequate model was determined using Akaike's Information Criterion with its lowest value after fitting the full model [31,32]. The analyses were conducted with $\mathrm{R}$ version 2.8.1 [33].

\section{Results}

The seven factors (two vegetation characteristics and five distances) were compared between the Xinjiang Ground-jay nest and non-nest plots. There were no significant differences between nest and non-nest plots for vegetation type (Chi-square test: $\chi^{2}=4.676$, $d f=2, p=0.097$ ) and vegetation cover (Table 1 ). 
Table 1. Pair-wise comparisons for ecological factors between nest and non-nest plots of Xinjiang Ground-jay. ( ${ }^{*}$ means significant difference and ${ }^{* *}$ means very significant difference).

\begin{tabular}{|c|c|c|c|c|}
\hline \multirow{2}{*}{ Factor } & \multicolumn{2}{|c|}{ Mean $\pm \mathrm{SE}$} & \multirow{2}{*}{$t$-Test } & \multirow{2}{*}{$\begin{array}{c}\text { Mann-Whitney } \\
U \text {-Test } P\end{array}$} \\
\hline & Nest Plots & Non-Nest Plots & & \\
\hline Vegetation cover $(\%)$ & $48.67 \pm 4.43$ & $42.17 \pm 2.01$ & - & $0.271^{\mathrm{NS}}$ \\
\hline Distance to water (km) & $2.00 \pm 0.20$ & $3.06 \pm 0.10$ & - & $0.001^{* *}$ \\
\hline Distance to path $(\mathrm{km})$ & $5.55 \pm 0.37$ & $4.48 \pm 0.21$ & - & $0.042 *$ \\
\hline Distance to settlement (km) & $6.38 \pm 0.25$ & $5.50 \pm 0.15$ & $0.004 *$ & - \\
\hline Distance to grazing land $(\mathrm{km})$ & $2.20 \pm 0.09$ & $1.30 \pm 0.21$ & - & $0.000 * *$ \\
\hline Distance to edge of oasis $(\mathrm{km})$ & $0.76 \pm 0.11$ & $0.43 \pm 0.04$ & - & $0.003 * *$ \\
\hline
\end{tabular}

A significant difference between the nest and non-nest plots was found for distance to water, distance to path, distance to settlement, distance to grazing land, and distance to the oasis edge (Table 1 ).

Distance to water, settlement, and the edge of oasis were the main variables that influenced the nest-site selection of the Xinjiang Ground-jay. The distance to water was negatively related to the possibility of nest-site selection, while the distance to settlement and edge of oasis were positively correlated with the possibility of nest-site selection (Table 2).

Table 2. Results of the minimum adequate model based on generalized linear models with the Xinjiang Ground-jay nest-site to the explanatory variables. Non-significant variables are not reported. The multivariate model was the best model according to Akaike's Information Criterion (AIC). $\beta$ : regression coefficient; $P$ : Likelihood Ratio Test. The AIC for the minimum adequate model was 116.81 .

\begin{tabular}{cccc}
\hline Explanatory Variables & $\boldsymbol{\beta}$ & SE & $\boldsymbol{P}$ \\
\hline Distance to water & -1.2045 & 0.2680 & $<0.0001$ \\
Distance to settlement & 1.0045 & 0.2531 & $<0.0001$ \\
Distance to edge of oasis & 1.3319 & 0.4598 & 0.0038 \\
\hline
\end{tabular}

\section{Discussion}

The results of our study showed that the distance to human settlements is one of the main factors influencing Xinjiang Ground-jay nest-site selection. Anthropogenic influence can negatively affect bird nest-site selection in many ways $[5,22,34]$, both directly and indirectly. Direct influence includes hunting, noise, and roadkill caused by traffic [34,35], while indirect anthropogenic influence involves human-induced habitat loss or habitat degeneration and human-associated activities, such as livestock grazing, which causes breeding interference and nest destruction [25]. The great distance of nest sites to the human settlement found in this study was possibly caused by the indirect anthropogenic influence. Local villagers are mainly farmers and shepherds; the former have established arable land near the settlement in areas previously covered by native forest, reducing the availability of suitable habitat for the Xinjiang Ground-jay. Additionally, shepherds bring their sheep and cattle to graze in the oasis daily. These activities drive individuals to nest far from human settlements to reduce the potential effects of anthropogenic influence on their breeding.

The nest-sites of the Xinjiang Ground-jay tended to be close to water sources, which may be caused by the arid environment. Water is essential for the survival of all living organisms, and thus, it is the most important environmental factor affecting their number and distribution [36]. Although water appears to play a less dominant role in forest ecosystems [37], it is an important factor affecting the nest-site selection of birds in arid or semi-arid environments [8]. Our study area was located in the Taklamakan Desert, featuring extreme dryness, high ambient temperatures, and scarce water. Together, these factors increase the rates of energy expenditure and water loss due to evaporation by the desert dwellers; therefore, access to water is a particularly important limiting factor for bird 
breeding success $[9,14,38]$. Accordingly, these individuals build nests near water sources to cope with dryness and high temperatures, which is consistent with observations of lesser prairie chickens (Tympanuchus pallidicinctus) and scaled quails (Callipepla squamata) [7,8].

Areas close to water generally have higher vegetation coverage and more species, which leads to an increased food abundance $[17,39]$. The Xinjiang Ground-jay is an omnivorous species, with adults mostly feeding on seeds and fruits, and young on lizards, insects, and other animals with high protein content [38]. Therefore, the Xinjiang Ground-jay builds nests close to water not only to overcome the disadvantages associated with drought, but also to obtain more food.

The distance to the edge of the oasis was also one of the main factors influencing the nest-site selection of ground jays as it can affect food availability and exposure to wind. In the desert environment, vegetation coverage and species richness in the oasis edge are lower than the central area. Thus, food availability, which is determined by species richness and abundance, is lower near the oasis edge than in the central areas [40,41]. Additionally, the wind speed near the oasis edge is higher than in the central area [42]. High wind speeds and their effects on sand are the main causes of reproductive failure of the Xinjiang Ground-jay in the desert [26]. Therefore, Xinjiang Ground-jays prefer to build nests further from the oasis edge.

Although the distance to the grazing land was not the main factor influencing Xinjiang Ground-jays' nest-site selection (Table 2), we found significant differences in the distances to grazing areas between the nest and non-nest plots, suggesting that these individuals may have avoided those areas (Table 1). As previously mentioned, livestock grazing disturbs bird incubation because they remove shrub leaves to eat, which directly destroys bird nests. The type of vegetation was also not a factor influencing the nest-site selection of the Xinjiang Ground-jay (Table 2), with no difference found between the nest and non-nest plots, probably because these are relatively limited in the study area. Xinjiang Ground-jays inhabit a desert with sparse vegetation composed of herbs, shrubs, and trees. Among them, most of the nest $(96 \%)$ and non-nest plots $(75 \%)$ were composed of shrubs.

\section{Conclusions}

The analysis of Xinjiang Ground-jays' nest-site selection showed that these individuals were influenced by a combination of human-induced habitat change and water and food availability in the desert. The results demonstrated the importance of resource availability in arid environments and highlight the effects of anthropogenic influence on nest-site selection. Whether these results can be applied to other desert-dwelling species requires further investigation; however, our study provides new insights to better understand the behavioral ecology of Xinjiang Ground-jays and assist their conservation efforts.

Supplementary Materials: The following are available online at https:/ / www.mdpi.com/article/10 $.3390 /$ su13115838/s1.

Author Contributions: Conceptualization, F.X. and W.Y.; methodology, F.X.; software, Y.T.; formal analysis, Y.T.; investigation, Y.T. and F.X.; writing-original draft preparation, Y.T., F.X., D.B. and W.Y.; funding acquisition, F.X. and W.Y. All authors have read and agreed to the published version of the manuscript.

Funding: This research was funded by the National Natural Science Foundation of China (No. 31401986) and China Biodiversity Observation Networks (Sino-BON).

Institutional Review Board Statement: The study was approved by the Ethics Committee of Xinjiang Institute of Ecology and Geography, Chinese Academy of Sciences (protocol code 20170321-1 and date of approval is 21 March 2017).

Informed Consent Statement: No applicable.

Data Availability Statement: The data presented in this study are available in Supplementary Materials here. 
Acknowledgments: We would like to thank Xinyun Li, Rui Yu, Yuliang Pan, Hongkui Zhang, and Hemin Zhang for their help with the fieldwork.

Conflicts of Interest: The authors declare no conflict of interest.

\section{References}

1. Cody, M.L. Habitat Selection in Birds; Academic Press: London, UK, 1985.

2. Clark, R.G.; Shutler, D. Avian habitat selection: Pattern from process in nest-site use by ducks? Ecology 1999, 80, $272-287$. [CrossRef]

3. Newell, F.L.; Rodewald, A.D. Role of topography, canopy structure, and floristics in nest-site selection and nesting success of canopy songbirds. For. Ecol. Manag. 2011, 262, 739-749. [CrossRef]

4. Yang, W.K.; Zhong, W.Q.; Gao, X.Y. A review of studies on avian habitat selection. Arid Zone Res. 2000, 17, 71-78.

5. Chen, X.B.; He, J.; Zhang, W. Ecological factors affecting choice of Pica sericea nest location in universities in Beijing. Sichuan J. Zool. 2006, 5, 855-857.

6. Keynan, O.; Yosef, R. Annual precipitation affects reproduction of the southern grey shrike (Lanius meridionalis). Wilson J. Ornithol. 2010, 122, 334-339. [CrossRef]

7. Grisham, B.A.; Borsdorf, P.K.; Boal, C.W.; Boydston, K.K. Nesting ecology and nest survival of lesser prairie-chickens on the Southern High Plains of Texas. J. Wildl. Manag. 2014, 78, 857-866. [CrossRef]

8. Kauffman, K.L.; Elmore, R.D.; Davis, C.A.; Fuhlendorf, S.D.; Goodman, L.E.; Hagen, C.A.; Tanner, E.P. Role of the thermal environment in scaled quail (Callipepla squamata) nest site selection and survival. J. Therm. Biol. 2021, 95, 102791. [CrossRef]

9. Tieleman, B.I.; Williams, J.B.; Visser, G.H. Energy and water budgets of larks in a life history perspective: Parental effort varies with aridity. Ecology 2004, 85, 1399-1410. [CrossRef]

10. Meng, D.K.; Min, X.J.; Zang, Y.X.; Ma, J.Y. Leaf nutrient characteristics and water use strategy of Tamarix ramosissima in artificial shelterbelt and natural community in south margin of the Taklamakan Desert, China. Chin. J. Ecol. 2019, 38, 3245-3253.

11. Zhang, J.T.; Wang, M.Z.; He, Q.; Pan, H.L.; Meng, L.; Wang, Y.H. Variation characteristics of nocturnal low-level jet in summer over the hinterland of Taklimakan Desert. J. Desert Res. 2020, 40, 90-101.

12. Zhou, S.S.; He, Q.; Jin, L.L.; Zhang, J.T. Radiation characteristics of the oasis-desert transition zone in the northern margin of the Taklimakan Desert: A case study of Xiaotang. J. Desert Res. 2020, 40, 43-51.

13. Noy-Meir, I. Desert ecosystems: Environment and producers. Annu. Rev. Ecol. Syst. 1973, 4, 25-51. [CrossRef]

14. Kozma, J.M.; Burkett, L.M.; Kroll, A.J.; Thornton, J.; Mathews, N.E. Factors associated with nest survival of Black-throated Sparrows, desert-breeding nest-site generalists. J. Field Ornithol. 2017, 88, 274-287. [CrossRef]

15. Li, C.F.; Fan, Y.; Zheng, X.Q.; Han, Z.Y.; Pan, H.L.; Chenglong, Z.; Chunrong, J. Changes in distribution and morphology of Tamarix ramosissima nebkhas in an oasis-desert ecotone. Geosci. J. 2021. [CrossRef]

16. Marini, M.A.; Robinson, S.K.; Heske, E.J. Edge effects on nest predation in the Shawnee National Forest, southern Illinois. Biol. Conserv. 1995, 74, 203-213. [CrossRef]

17. Martin, T.E.; Roper, J.J. Nest predation and nest-site selection of a western population of the hermit thrush. Condor 1988, 90, 51-57. [CrossRef]

18. Marina, M.; Juan, C.A.; Luis, M.B. Nest-site selection by Great Bustards Otis tarda suggests a trade-off between concealment and Visibility. Ibis 2010, 152, 77-89.

19. Davis, H.T.; Long, A.M.; Baumgardt, J.A.; Campbell, T.A.; Morrison, M.L. Factors affecting nest success and predator assemblage of breeding birds in semiarid grasslands. Rangel. Ecol. Manag. 2019, 72, 385-395. [CrossRef]

20. Rao, S.; Koli, V.K. Edge effect of busy high traffic roads on the nest site selection of birds inside the city area: Guild response. Transp. Res. D 2017, 51, 94-101. [CrossRef]

21. Barros, R.; Medrano, F.; Silva, R.; Schmitt, F.; Malinarich, V.; Teran, D.; Peredo, R.; Pinto, C.; Vallverdu, A.; Fuchs, J.; et al. Breeding sites, distribution and conservation status of the White-vented storm-petrel Oceanites gracilis in the Atacama Desert. Ardea 2020, 108, 203-212. [CrossRef]

22. Pasinelli, G.; Grendelmeier, A.; Gerber, M.; Arlettaz, R. Rodent-avoidance, topography and forest structure shape territory selection of a forest bird. BMC Ecol. 2016, 16, 24. [CrossRef]

23. Salek, M.; Grill, S.; Riegert, J. Nest-site selection of an avian urban exploiter the Eurasian magpie Pica pica, across the urban-rural gradient. J. Vertebr. Biol. 2021, 70, 20086.

24. Rosich, J.; Peris, A.; Mampel, T.; Hernández-Matías, A.; Miño, À.; Real, J. Northern Goshawk breeding sites indicate the presence of mature forest in Mediterranean pinewoods. Forest Ecol. Manag. 2021, 479, 118602. [CrossRef]

25. Ma, M. Xinjiang Ground-Jay Podoces Biddulphi, an Endemic Species in Taklimakan Desert; Xinjiang Science and Technology Press: Urumqi, China, 2004.

26. Zhang, W.G. Passive Microwave Remote Sensing on Sand Desert Area-Takliman Sand Desert as a Case Study; Institute of Remote Sensing Applications Chinese Academy of Science: Beijing, China, 2004.

27. Jin, C.N. Highway Construction and Sand Hazard Controlling Research in Active Dune Region in the Taklamakan Desert; Lanzhou University: Lanzhou, China, 2006.

28. Fang, C.; Hou, W.L. Status and analysis of desertification in Minfeng county. Xinjiang Agric. Sci. 2006, 43, 68-69.

29. Ma, M. Status of the Xinjiang Ground-jay: Population, breeding ecology and conservation. Chin. Birds 2011, 2, 59-62. [CrossRef] 
30. Gao, X.Y. A Checklist on the Classification and Distribution of Vertebrate Species and Subspecies in Xinjiang; Xinjiang Science and Technology Press: Urumqi, China, 2005.

31. Burnham, K.; Anderson, D. Model Selection and Multimodel Inference: A Pratical Information-Theoretic Approach; Springer: New York, NY, USA, 2002.

32. Richards, S.A. Testing ecological theory using the information-theoretic approach: Examples and cautionary results. Ecology 2005, 70, 220-228. [CrossRef]

33. R Core Development Team. R: A Language and Environment for Statistical Computing; R Foundation for Statistical Computing: Vienna, Austria, 2006.

34. Zhang, W.W.; Shi, J.Z.; Huang, H.Q.; Liu, T. The impact of disturbance from photographers on the Blue-crowned Laughing thrush (Garrulax courtoisi). Avian Conserv. Ecol. 2017, 12, 15. [CrossRef]

35. Ru, S.G.; Liu, Y.; Hou, W.L.; Li, D.Y. The breeding ecology and nest habitat selection of Azure-Winged magpie (Cyanopica cyana) I. The breeding ecology. Chin. J. Ecol. 1997, 16, 23-27.

36. Ge, F. Modern Ecology; The Science Press: Beijing, China, 2008.

37. Foggia, J.R.; Rush, S.A.; Miller, D.A.; Wigley, T.B.; Martin, J.A. Effects of forest structure and harvest-induced edges on predation risk. Wildl. Soc. Bull. 2018, 42, 237-245. [CrossRef]

38. Tieleman, B.I.; Williams, J.B. The adjustment of avian metabolic rates and water fluxes to desert environments. Physiol. Biochem. Zool. 2000, 73, 461-479. [CrossRef]

39. Martin, T.E.; Scott, J.; Menge, C. Nest predation increases with parental activity: Separating nest site and parental activity effects. Proc. Biol. Sci. 2000, 267, 2287-2293. [CrossRef]

40. Burhans, D.E.; Thompson, F.R., III. Relationship of songbird nest concealment to nest fate and flushing behavior of adults. Auk 2001, 118, 237-242. [CrossRef]

41. Stauffer, G.E.; Diefenbach, D.R.; Marshall, M.R.; Brauning, D.W. Nest success of grassland sparrows on reclaimed surface mines. J. Wildl. Manag. 2011, 75, 548-557. [CrossRef]

42. Wang, Y.B. Characteristics of the Surface Wind in the Southern Margin of Taklamakan; Sichuan Normal University: Chengdu, China, 2018. 